\title{
日本病院学会臨床予防医学委員会報告
}

—人間ドック・自動化健診の現況*

社団法人 日 本 病 院 会

\section{I 日本病院会人間ドック指定病院及び自動化健診指定施設}

都道府県別一覧表

\begin{tabular}{|c|c|c|c|c|c|c|c|c|}
\hline & 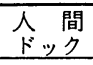 & $\begin{array}{l}\text { 夏動化 } \\
\text { 煡 診 }\end{array}$ & & $\begin{array}{l}\text { 人間 } \\
\text { ドック }\end{array}$ & $\begin{array}{l}\text { 自動化 } \\
\text { 健 䛦 }\end{array}$ & & 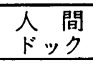 & $\begin{array}{l}\text { 自動化 } \\
\text { 健 診 }\end{array}$ \\
\hline 北海 道 & 5 & 3 & 新 潟 県 & 25 & 2 & 岡山県 & 8 & 1 \\
\hline 青 森 県 & 4 & 1 & 富山県 & 5 & 1 & 広島県 & 7 & 4 \\
\hline 岩手県 & 7 & & 石川県 & 6 & & 山口県 & 10 & 1 \\
\hline 宮 城 県 & 6 & 2 & 福井県 & 2 & & 徳島 県 & 2 & \\
\hline 秋田県 & 3 & & 岐阜県 & 5 & 1 & 香川県 & 2 & \\
\hline 山形 県 & 1 & & 静 岡県 & 30 & 6 & 愛媛 県 & 7 & \\
\hline 福島県 & 9 & & 愛, 知 県 & 14 & 7. & 高 知 県 & 2 & 1 \\
\hline 茨城県 & 9 & 2 & 三重県 & 8 & & 福岡県 & 24 & 6 \\
\hline 杤 木県 & 4 & & 滋賀県 & 8 & & 佐賀県 & 2 & \\
\hline 群 馬県 & 12 & 1 & 京 都 府 & 12 & 1 & 長 崎県 & 1 & \\
\hline 埼玉県 & 6 & 4 & 大阪 府 & 17 & 11 & 熊本 県 & 4 & \\
\hline 千葉 県 & 11 & & 奈良県 & 1 & & 大分県 & 1 & 2 \\
\hline 東 京 都 & 63 & 25 & 和歌山県 & 1 & & 宮 崎県 & 1 & \\
\hline 神奈川県 & 28 & 4 & 兵庫県 & 13 & 1 & 鹿児島県 & 2 & \\
\hline 山梨県 & 7 & & 鳥取 県 & 2 & & 沖縄県 & & 1 \\
\hline 長 野 県 & 4 & & 島根県 & 3 & & & 404 & 88 \\
\hline
\end{tabular}

合計 人間ドック指定病院 404 自動化健診指定施設 88

注 (1) 人間ドック指定病院中, 新病棟建築中並びに医師, 看護婦不足等 の事由により一時休止病院が13含まれている。

(2) 人間ドック指定病床は 1,581 床である。

(3) 人間ドック新指定病院 29 病院 人間ドック廃止病院 2 病院

（退会他）

自動化健診新指定施設 13 施設 自動化健診廃止施設 なし

(4) 健康保険組合連合会加入組合は，1,747組合である（昭61.3.31現 在）が，この中，人間ドック利用組合は 1,151 組合 $(65.8 \%)$. 自動 化健診利用組合は，531組合 (30.4\%) である。

* 昭和 61 年 3 月末日現在 


\section{II 人間ドック指定病院経営主体別一覧（404病院）}

\begin{tabular}{|c|c|c|c|c|c|c|c|c|c|c|c|c|c|c|c|c|c|c|c|c|}
\hline 設 & 厚 & $\begin{array}{l}\text { 郵 } \\
\text { 政 } \\
\text { 省 }\end{array}$ & 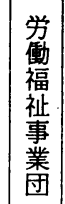 & $\begin{array}{l}\text { 都 } \\
\text { 道 } \\
\text { 府 } \\
\text { 県 }\end{array}$ & $\begin{array}{l}\text { 町 } \\
\text { 村 }\end{array}$ & $\begin{array}{l}+ \\
\text { 字 }\end{array}$ & 生 & 厚 & $\begin{array}{l}\text { 全 } \\
\text { 社 } \\
\text { 連 }\end{array}$ & $\begin{array}{l}\text { 㚖 } \\
\text { 生 } \\
\text { 団 }\end{array}$ & 保 & $\begin{array}{l}\text { 健 } \\
\text { 保 } \\
\text { 及 } \\
\text { 連 } \\
\text { 合 }\end{array}$ & $\begin{array}{l}\text { 共 } \\
\text { 済 } \\
\text { 及 } \\
\text { 連 } \\
\text { 合 }\end{array}$ & $\begin{array}{l}\text { 公 } \\
\text { 益 } \\
\text { 法 } \\
\text { 人 }\end{array}$ & $\begin{array}{c}\text { 医 } \\
\text { 療 } \\
\text { 法 } \\
\text { 人 }\end{array}$ & $\begin{array}{l}\text { 学 } \\
\text { 校 } \\
\text { 法 } \\
\text { 人 }\end{array}$ & 会 & $\begin{array}{l}\text { そ } \\
\text { の } \\
\text { 他 } \\
\text { 法 } \\
\text { 人 }\end{array}$ & 個 & 計 \\
\hline 院 & 2 & 1 & 3 & 18 & 48 & 48 & 21 & 19 & 26 & 3 & 3 & 7 & 9 & 33 & 120 & 6 & 6 & 15 & 16 & 4 \\
\hline & 0.5 & 0.2 & 0.8 & 4.4 & 11.9 & 11.9 & & 4.7 & 6.4 & 0.8 & 0.8 & 1.7 & 2.2 & 8.2 & 29.7 & 1.5 & 1.5 & 3.7 & 3.9 & 100 \\
\hline
\end{tabular}

III人間ドック指定病院の推移

(……病会指定病院数——゙ック実施報告病院数）

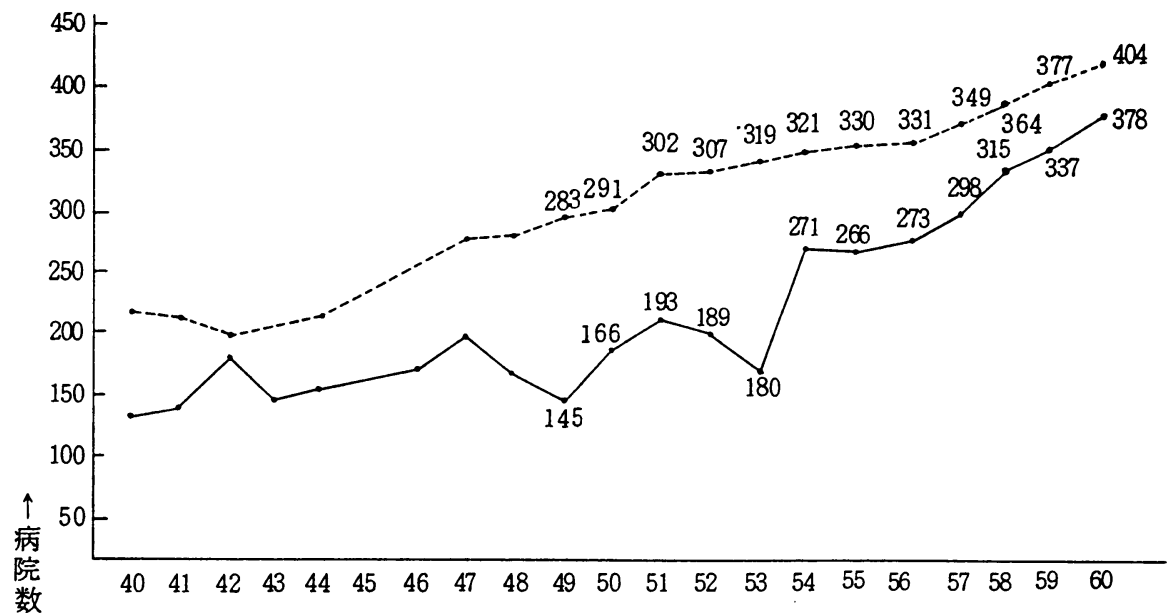
年度別 $\rightarrow$

注 (1) 指定病院は漸増の傾向にある。

(2) 実施状況報告病院は93.6\%である。(一時休止を除く回答率は $96.7 \%$ ) 


\section{IV 自動化健診指定施設の推移}

\section{(……病会指定施設数 一一自動化実施報告施設数）}

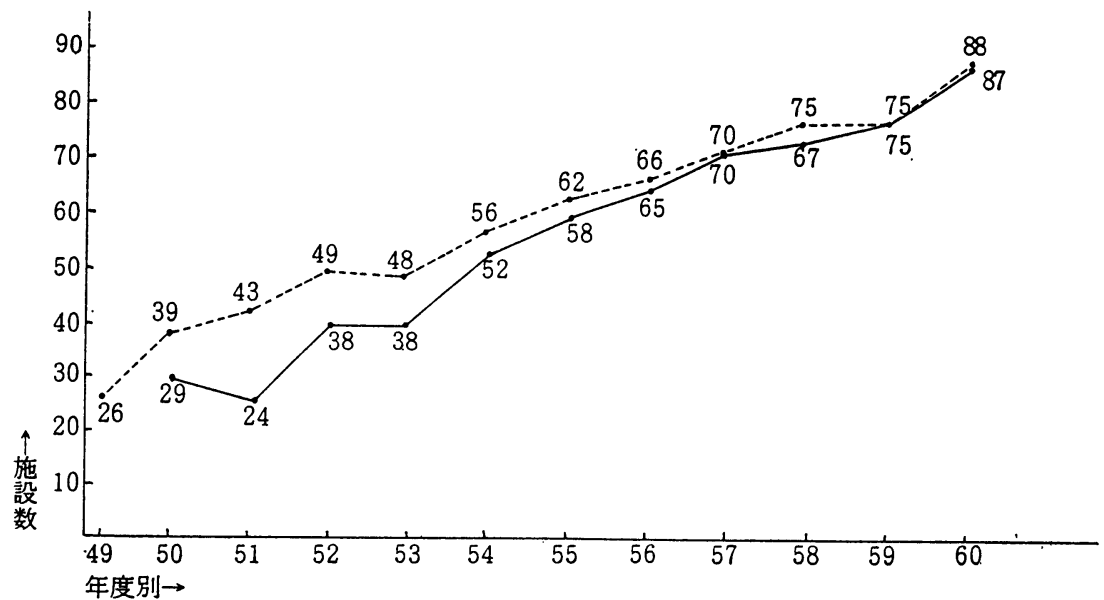

注 (1) 指定施設は増加の傾向にある。（他にも，申請手続き中のものが11施 設ある)

（2）実施状況報告施設は $98.9 \%$ である。

V人間ドック，自動化健診実施状況調査（昭和60.1.1 60.12.31）日病会 員約 2,100 の病院施設に対してアンケートの提出を求めたが，報告提出は 529 病院と自動化健診101施設であった。

○短期人間ドック実施病院 529 [健保連契約（指定）病院 378] ○自動化健診実施施設 101 〔健保連契約（指定）施設 87〕

（1） 日病会指定病院における各種人間ドックの実施報告 378 病院

\begin{tabular}{|c|c|c|c|}
\hline \multirow[b]{2}{*}{ 種別 } & \multicolumn{3}{|c|}{ 受診者数（昭和60年 1月～12月） } \\
\hline & 男 (人) & 女(人) & 計（人） \\
\hline 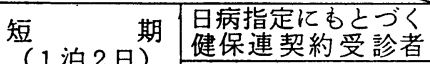 & 52,240 & 10,162 & 62,402 \\
\hline ドック ク & 83,067 & 23,006 & 106,073 \\
\hline 小 & 135,307 & 33,168 & 168,475 \\
\hline 日病指定 主 婦 検 診 & & 9,101 & 9,101 \\
\hline 日病指定 小 児 検 診 & 432 & 386 & 818 \\
\hline 1 週 間 ド ッ ク & 516 & 114 & 630 \\
\hline その他入院ドック（ $3 \sim 4$ 日） & 3,024 & 866 & 3,890 \\
\hline 外来ドック (多 項 目) & 88,475 & 43,712 & 132,187 \\
\hline 部分検診 (胃・子宮・胸・循環器等) & 165,126 & 213,985 & 379,111 \\
\hline 団 & 689,053 & 364,395 & $1,053,448$ \\
\hline 総 & $1,081,933$ & 665,727 & $1,747,660$ \\
\hline
\end{tabular}

（注）精度管理サーベイ参加状況312病院（77.2\%）が日本医師会等へ参加 
（2）日病会指定施設における自動化健診受診者報告 87施設

\begin{tabular}{|c|c|c|c|c|}
\hline \multirow{2}{*}{\multicolumn{2}{|c|}{ 種 }} & \multicolumn{3}{|c|}{ 受 診 者 (昭和 60 年 1 月～12月) } \\
\hline & & 男 (人) & 女(人) & 計（人） \\
\hline \multirow{2}{*}{ 自動化健診 } & 健保連契約（指定） & 137,064 & 58,386 & 195,450 \\
\hline & 健 保 連 以外 & 213,931 & 100,972 & 314,903 \\
\hline 総 & 計 & 350,995 & 159,358 & 510,353 \\
\hline
\end{tabular}

（注）精度管理サーベー参加状況 87 施設 (100\%) が日本総合健診医学会等へ参加

（3）その他日病会員病院における各種人間ドックの実施報告 151 病院

\begin{tabular}{|c|c|c|c|}
\hline \multirow[b]{2}{*}{ 種 別 } & \multicolumn{3}{|c|}{ 受診者数（昭和60年 1月～12月） } \\
\hline & 男（人） & 女(人) & 計 (人) \\
\hline 短期（1 泊. 2 日）ドック & 29,530 & 9,615 & 39,145 \\
\hline 婦 検 診 & & 2,409 & 2,409 \\
\hline 児 検 & 312 & 297 & 609 \\
\hline 1 週 間 & 100 & 21 & 121 \\
\hline その他入院ドック（3〜4日） & 3,808 & 718 & 4,526 \\
\hline 外来ドック（多項目） & 53,820 & 24,416 & 78,236 \\
\hline 部分検診 (胃・子宮・胸・循環器等) & 156,078 & 87,166 & 243,244 \\
\hline 団 & 276,521 & 135,404 & 411,925 \\
\hline 総 & 520,169 & 260,046 & 780,215 \\
\hline
\end{tabular}

（注）精度管理サーベイ参加状況71病院 (47.0\%) が日本医師会等へ参加

（4）その他日病会員施設における自動化健診受診者報告 14施設

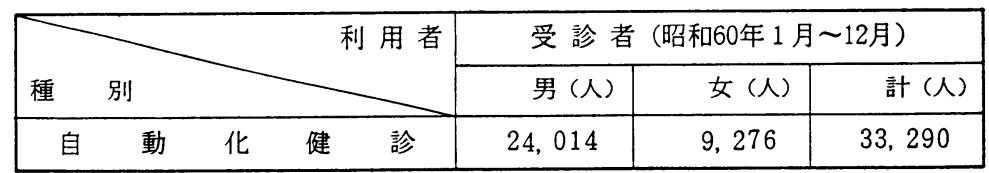

（注）精度管理サーベイ参加状況11施設 $(78.6 \%)$ が日本医師会等へ参加

（5）短期（1 泊 2 日）ドック実施病床数

\begin{tabular}{|r|c|c|c|}
\hline 実施病床別 & 健保連契約(指定) & その 他 & 計 \\
\hline 日 病 指 定 病 院 (報告 378 病院) & 1,488 & 836 & 2,324 \\
\hline その他日病会員病院 (報告 151 病院) & & 642 & 642 \\
\hline
\end{tabular}

（6）自動化健診 1 日実施可能人数

\begin{tabular}{|l|c|l|}
\hline & 1 日実施可能数 & 平 均 \\
\hline 日 病 指 定 施 設(報告 87 施設) & 3,119 名 & 35.8 名 \\
\hline その他日病会員施設 (報告 14 施設) & 276 名 & 19.7 名 \\
\hline
\end{tabular}


VI 短期人間ドック受診者年度別推移

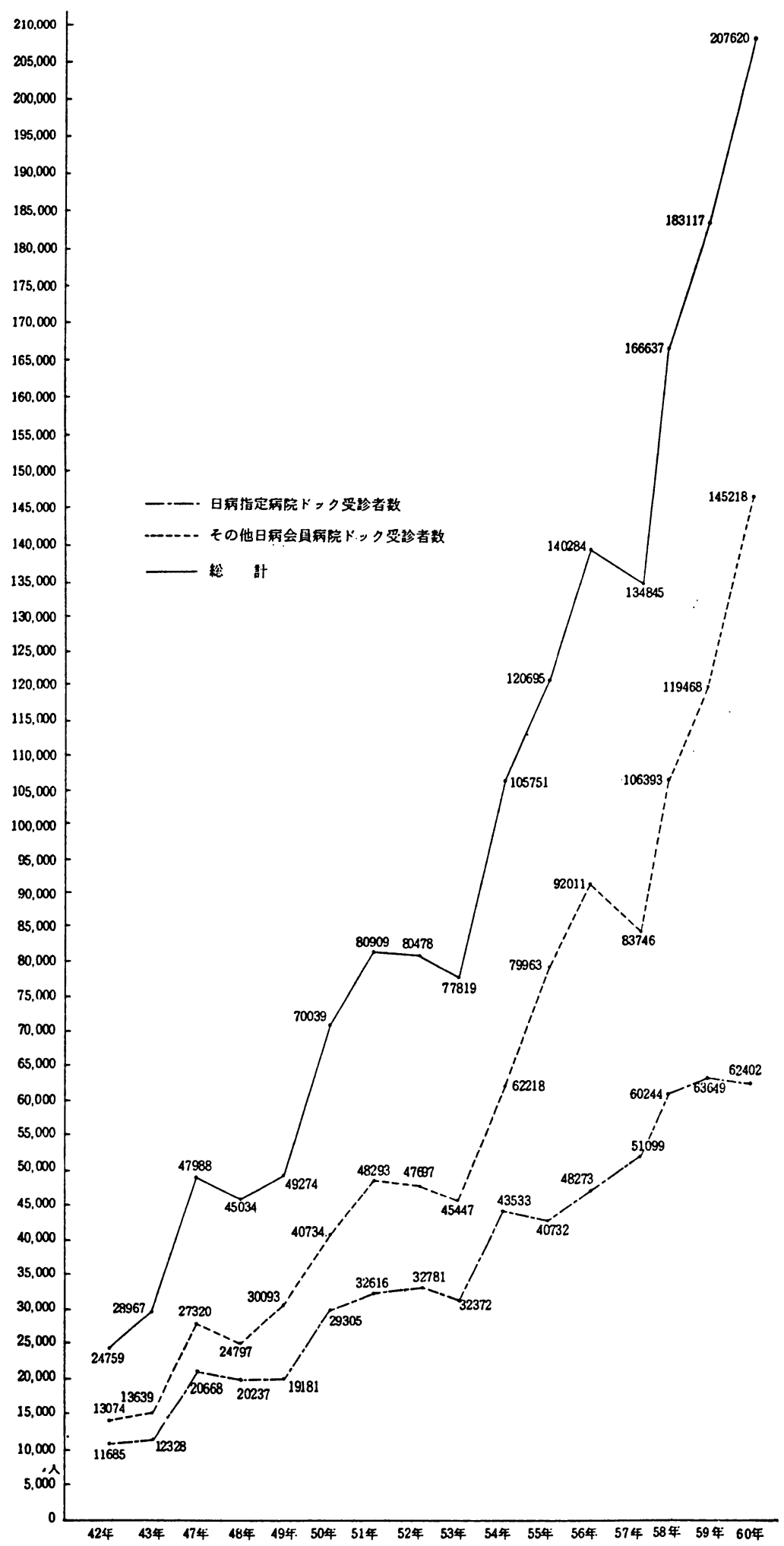




\section{VII 自動化健診受診者年度別推移}

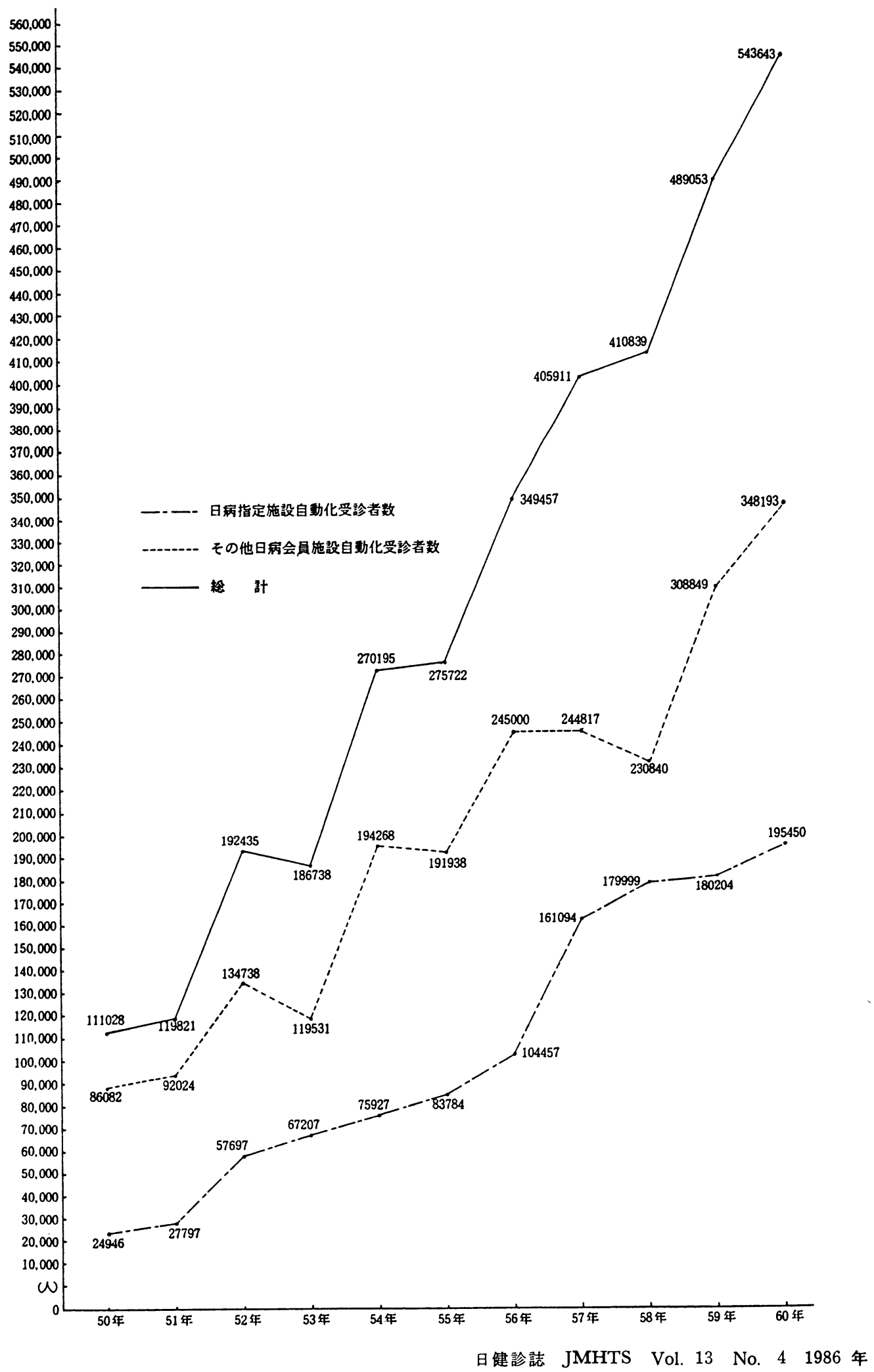


一地域別比較一

\begin{tabular}{|c|c|c|c|}
\hline ブロック & 指定病院数 & 返信数 & $\%$ \\
\hline 北 海 道 & 5 & 3 & 60.0 \\
\hline 東 & 28 & 18 & 64.3 \\
\hline 関東・甲信越 & 159 & 79 & 49.7 \\
\hline 東海·北陸 & 68 & 40 & 58.6 \\
\hline 粗 & 48 & 27 & 56.3 \\
\hline 中国 ·四国 & 42 & 24 & 57.1 \\
\hline 九 & 31 & 14 & 45.2 \\
\hline 計 & 381 & 205 & 53.8 \\
\hline
\end{tabular}

\begin{tabular}{|c|c|}
\hline \begin{tabular}{r|} 
非指定病院 \\
数
\end{tabular} & $\begin{array}{c}\text { 調查牒豪 } \\
\text { 数 }\end{array}$ \\
\hline 0 & 3 \\
\hline 4 & 22 \\
\hline 10 & 89 \\
\hline 9 & 49 \\
\hline 5 & 32 \\
\hline 1 & 25 \\
\hline 5 & 19 \\
\hline 34 & 239 \\
\hline
\end{tabular}

自動化検診施設のアンケート返信数

一地域別比較一

\begin{tabular}{|c|c|c|c|}
\hline ブロック & 指定病院数 & 返信数 & $\%$ \\
\hline 北 海 道 & 3 & 2 & 66.7 \\
\hline 北 & 3 & 2 & 66.7 \\
\hline 関東 - 甲信越 & 34 & 13 & 38.2 \\
\hline 東海・北陸 & 11 & 6 & 54.5 \\
\hline 近 & 11 & 6 & 54.5 \\
\hline 中国·四国 & 6 & 6 & 100.0 \\
\hline 九州·沖縄 & 7 & 5 & 71.4 \\
\hline 計 & 75 & 40 & 53.3 \\
\hline
\end{tabular}

\begin{tabular}{|c|c|}
\hline 未指定病院 & 調查対象䘚数 \\
\hline 0 & 2 \\
\hline 0 & 2 \\
\hline 3 & 16 \\
\hline 2 & 8 \\
\hline 2 & 8 \\
\hline 1 & 7 \\
\hline 1 & 6 \\
\hline 9 & 49 \\
\hline
\end{tabular}

施設別・アンケート返信内容の比較

\begin{tabular}{|c|c|c|c|c|c|}
\hline & アンケ返信数 & 項目別統討 & $\%$ & 癌症例別 & $\%$ \\
\hline 人間ドッ多定病院 & 205 & 196 & 95.6 & $146 \quad(71)$ & 71.2 \\
\hline 人間ト品名指定病院 & 34 & 33 & 97.0 & $27 \quad(10)$ & 79.4 \\
\hline 自動化健詮定施設 & 40 & 39 & 97.5 & (2) & 67.5 \\
\hline $\begin{array}{c}\text { 自動化集詮定施設 } \\
\text { 謨 }\end{array}$ & 9 & 9 & 100.0 & (3) & 100.0 \\
\hline 計 & 288 & 277 & 96.2 & $209 \quad(86)$ & 72.6 \\
\hline
\end{tabular}

（注）（）内の数字は癌症例該当者なしと返信した施設数 
人間ドック・自動化

\begin{tabular}{|c|c|c|c|c|c|c|}
\hline 年 代 別 & \multicolumn{3}{|c|}{39 歳以下 } & \multicolumn{3}{|c|}{$40 \sim 49$ 歳 } \\
\hline 異常なし（A＋B） & 人数 $(33$, & $\begin{array}{l}\text { 1) } \\
\text { 受部者数 }\end{array}$ & $89,045)$ & 人数 $(51 ; 05$ & 6) 受診者数 & $(163,944)$ \\
\hline 判定 & $B F+C$ & $\mathrm{D}$ & $G$ & $B F+C$ & $\mathrm{D}$ & $G$ \\
\hline 满 & 11,282 & 520 & 111 & 24,589 & 2,494 & 197 \\
\hline 呼吸器疾患 & 814 & 90 & 554 & 2,637 & 250 & 1,692 \\
\hline 高 血 壬 & 3,579 & 596 & 349 & 10,913 & 3,559 & 879 \\
\hline 高コレステロール血 & & & & & & \\
\hline 高中性脂肪血 & 7,268 & 682 & 945 & \rfloor$_{17,593}$ & 1,826 & 1,869 \\
\hline 高尿酸血 & 1,299 & 177 & 234 & 2,717 & 438 & 418 \\
\hline 心電図異常 & 3,484 & 189 & 854 & 7,976 & 778 & 2,228 \\
\hline 緊・賠胱疾患 & 3,796 & 236 & 1,589 & 8,410 & 499 & 3,709 \\
\hline 胃 溃 瘍 & & & & & & \\
\hline 十二指腸漬瘍 & 1,940 & 737 & 4,080 & 4,236 & 1,605 & 8,541 \\
\hline 胆石・胆要炎 & 499 & 89 & 479 & 1,514 & 331 & 1,413 \\
\hline 肝機能障害 & 6,999 & 582 & 2,277 & 14,881 & 1,425 & 4,538 \\
\hline その他の消化器疾患 & 2,785 & 266 & 2,146 & 6,091 & 638 & 5,049 \\
\hline 糖 尿 病 & 6,518 & 542 & 1,864 & 17,254 & 2,473 & 5,292 \\
\hline 血液疾患 & 3,982 & 495 & 1,230 & 8,618 & 1,262 & 2,810 \\
\hline 血清梅毒反応 & & & & & & \\
\hline リウマチ疾患 & 1,186 & 36 & 316 & 2,176 & 139 & 680 \\
\hline 眼 & 699 & 166 & 745 & 2,421 & 657 & 1,642 \\
\hline 肛門 - 直腸疾患 & 627 & 212 & 201 & 2,112 & 705 & 543 \\
\hline 前立腺疾患 & 255 & 230 & 228 & 602 & 472 & 515 \\
\hline 婦人科 & 1,195 & 622 & 578 & 2,611 & 1,462 & 1,278 \\
\hline 乳房疾患 & 109 & 5 & 310 & 243 & 17 & 504 \\
\hline その他の疾患 & 2,661 & 526 & 679 & 6,769 & 1,435 & 1,731 \\
\hline 計 & 60,977 & 6,998 & 19,769 & 144,363 & 22,465 & 45,528 \\
\hline
\end{tabular}

A ‥異常なし B ‥軽度の異常が認められるが日常生活に差支えなし 
健診全国成績総合計（昭和59年 1 月～12月）

\begin{tabular}{|c|c|c|c|c|c|c|c|c|}
\hline \multicolumn{3}{|c|}{$50 \sim 59$ 歳 } & \multicolumn{3}{|c|}{60 歳以上 } & \multicolumn{3}{|c|}{ 総 計 } \\
\hline \multicolumn{3}{|c|}{$\begin{array}{l}\text { 人数 }(31,520) \\
\text { 受診者数 }(127,122)\end{array}$} & \multicolumn{3}{|c|}{ 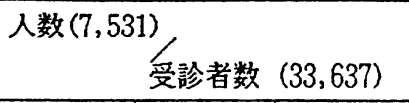 } & \multicolumn{3}{|c|}{$\begin{array}{l}\text { 人数 }(123,198) \\
\text { 受診者数 } \quad(413,748)\end{array}$} \\
\hline$B F+C$ & $\mathrm{D}$ & G & $B F+C$ & $\mathrm{D}$ & G & $B F+C$ & $\cdot D$ & G \\
\hline 21,177 & 2,671 & 212 & 6,679 & 881 & 66 & 63,727 & 6,566 & 586 \\
\hline 4,577 & 429 & 2,154 & 2,124 & 221 & 896 & 10,152 & 990 & 5,296 \\
\hline 12,828 & 6,772 & 1,212 & 4,288 & 2,851 & 474 & 31,608 & 13,778 & 2,914 \\
\hline$]_{16,360}$ & 1,777 & 1,604 & 3,981 & 455 & 341 & $45 ; 202$ & 4,740 & 4,759 \\
\hline 2,327 & 427 & 393 & 590 & 152 & 69 & 6,933 & 1,194 & 1,114 \\
\hline 8,515 & 1,616 & 2,736 & 3,118 & 782 & 1,080 & 23,093 & 3,365 & 6,898 \\
\hline 7,786 & 599 & 3,844 & 2,609 & 258 & 1,023 & 22,601 & 1,592 & 10,165 \\
\hline 3,438 & 1,785 & 7,738 & 942 & 468 & 1,994 & ]$_{10,556}$ & 4,595 & 22,353 \\
\hline 1,987 & 494 & 1,600 & 853 & 163 & 618 & 4,853 & 1,077 & 4,110 \\
\hline 11,249 & 1,563 & 3,745 & 2,593 & 378 & 865 & 35,722 & 3,948 & 11,425 \\
\hline 5,582 & 786 & 5,776 & 1,670 & 260 & 1,903 & 16,128 & 1,950 & 14,874 \\
\hline 16,944 & 3,672 & 5,697 & 4,378 & 1,220 & 1,729 & 45,094 & 7,907 & 14,582 \\
\hline 7,044 & 559 & 1,933 & 2,243 & 181 & 567 & 21,887 & 2,497 & 6,540 \\
\hline 2,100 & 176 & 713 & 745 & 90 & 304 & 6,207 & 441 & 2,013 \\
\hline 4,115 & 1,023 & 1,784 & 1,628 & 581 & 793 & 8,863 & 2,433 & 4,964 \\
\hline 2,255 & 808 & 718 & 713 & 185 & 264 & 5,707 & 1,910 & 1,726 \\
\hline 822 & 545 & 618 & 334 & 142 & 157 & 2,013 & 1,389 & 1,518 \\
\hline 1,716 & 863 & 814 & 409 & 190 & 183 & 5,931 & 3,137 & 2,853 \\
\hline 112 & 12 & 167 & 31 & 7 & 45 & 495 & 41 & 1,026 \\
\hline 7,560 & 1,703 & 1,671 & 2,961 & 467 & 646 & 19,951 & 4,131 & 4,727 \\
\hline 138,494 & 28,286 & 45,129 & 42,889 & 9,932 & 14,017 & 386,723 & 67,681 & 124,443 \\
\hline
\end{tabular}

BF …経過観察を要する C …要注意 D …要治療 G …要精検 
日本総合健診医学会誌

総合健診と胃集検の胃癌発見率

\begin{tabular}{|c|c|c|c|c|}
\hline & $\begin{array}{l}\text { 件 } \\
\text { 数 }\end{array}$ & 受診者数 & 発見胃窝数 & 胃琴発見率 \\
\hline 人間ドック 指定病院 & 146 & 118,740 & 153 & 0.13 \\
\hline 人間ドック 未指定病院 & 27 & 18,814 & 27 & 0.14 \\
\hline 自動化健診 指定施設 & 27 & 234,342 & 240 & 0.10 \\
\hline 自動化健祅 未指定施設 & 9 & 39,119 & 40 & 0.10 \\
\hline 紛 計 & 209 & $411 ; 015$ & 460 & 0.11 \\
\hline $\begin{array}{l}\text { 昭和57年度 } \\
\text { 胃集検全国集計 }\end{array}$ & & 383,671 & 494 & 0.13 \\
\hline
\end{tabular}

（註）胃集検は施設検診成績を示す

早期胃癌・進行胃癌の割合

\begin{tabular}{|c|c|c|c|c|c|c|c|}
\hline & \multirow{2}{*}{$\begin{array}{l}\text { 件 } \\
\text { 数 }\end{array}$} & \multicolumn{2}{|c|}{ 早期胃窖 } & \multicolumn{2}{|c|}{ 進行胃琶 } & \multicolumn{2}{|c|}{ 計 } \\
\hline & & 症例数 & $\%$ & 症例数 & $\%$ & 症例数 & $\%$ \\
\hline 人間ドック 指定病院 & 146 & 108 & 70.6 & 45 & 29.4 & 153 & 100.0 \\
\hline 人間ドック 未指定病院 & 27 & 18 & 66.7 & 9 & 33.3 & 27 & 100.0 \\
\hline 自動化健㟝 指定施設 & 27 & 171 & 71.3 & 69 & 28.7 & 240 & 100.0 \\
\hline 自動化健診 未指定施設 & 9 & 25 & 62.5 & 15 & 37.5 & 40 & 100.0 \\
\hline 総 & 209 & 322 & 70.0 & 128 & 30.0 & 460 & 100.0 \\
\hline $\begin{array}{l}\text { 昭和57年度 } \\
\text { 胃集検全国集計 }\end{array}$ & & 261 & 52.8 & 233 & 47.2 & 494 & 100.0 \\
\hline
\end{tabular}

（註）胃集検は施設検診成績を示す 


\section{人間ドック・自動化健診で発見した臓器別癌発見率の比較}

全体の癌を 100 として, 各臓器別の割合を表示（子宮・乳癌を除く）

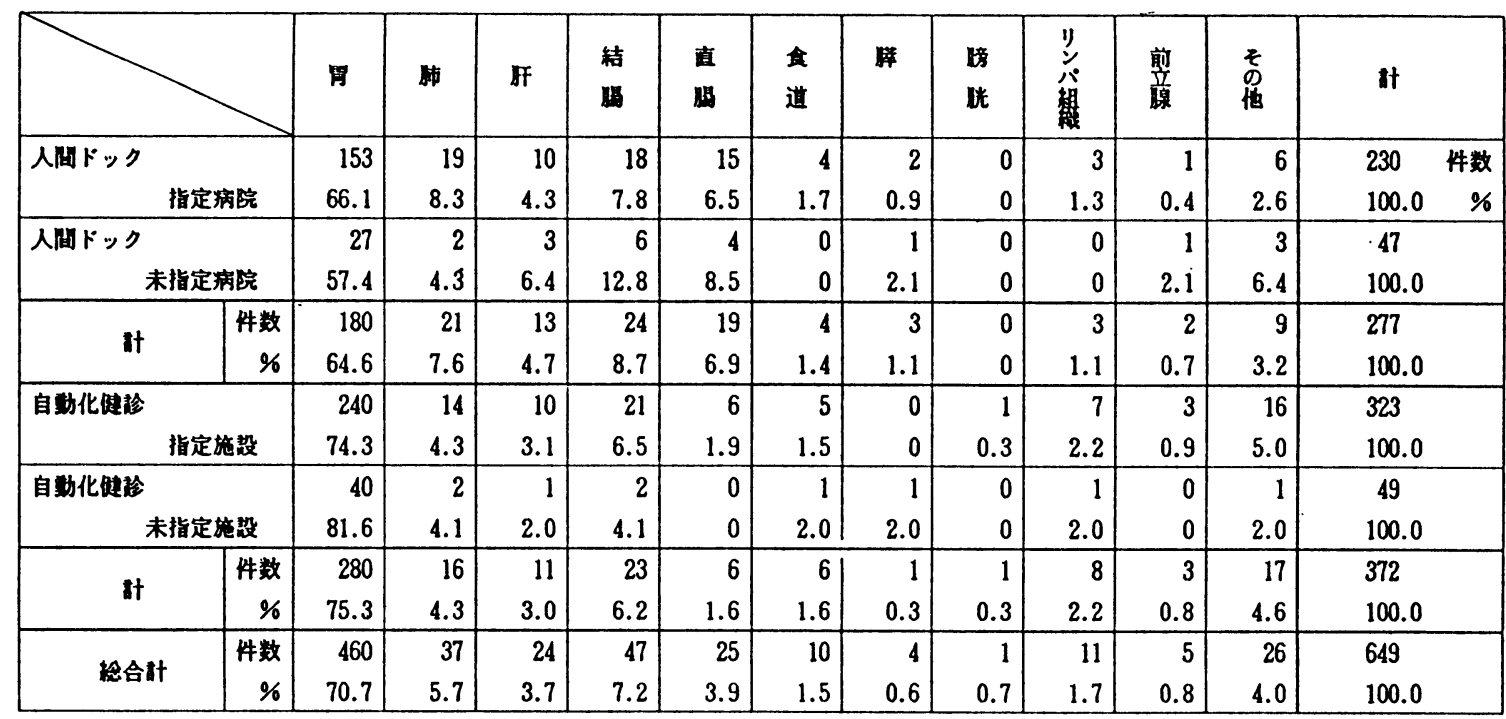

発見胃癌の検討 (460例)

\begin{tabular}{|c|c|c|c|c|c|c|c|c|c|c|c|c|c|c|c|c|c|c|c|}
\hline & \multicolumn{2}{|c|}{ 性 } & \multicolumn{2}{|r|}{ 年 } & \multicolumn{2}{|l|}{ 代 } & \multicolumn{2}{|c|}{$O P$} & \multicolumn{2}{|c|}{ 覀家系 } & \multicolumn{3}{|c|}{ 受埥回数 } & \multicolumn{2}{|c|}{ 自其症状 } & \multicolumn{3}{|c|}{ 他满度 } \\
\hline & & $\sigma^{7}$ & $q$ & 章 & 喿 & 吾 & $\begin{array}{l}\text { 六以 } \\
\text { 藏上 }\end{array}$ & 有 & 無 & 有 & 無 & $\begin{array}{l}1 \\
\text { 回 }\end{array}$ & $1_{5}$ & $\begin{array}{l}6 \text { 以 } \\
\text { 回上 }\end{array}$ & 有 & 無 & やせ & 兽通 & 㸭被 \\
\hline \multirow{2}{*}{ 人周ドック } & 应㽗数 & 142 & 38 & 16 & 35 & 74 & 55 & 163 & 16 & 62 & 117 & 110 & 55 & 14 & 70 & 109 & 28 & 107 & 44 \\
\hline & $\%$ & & & & & & & 91.1 & 8.9 & 34.6 & 65.4 & 61.5 & 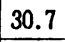 & 7.8 & 39.1 & 60.9 & 15.6 & 59.9 & 24.5 \\
\hline \multirow{2}{*}{$\begin{array}{r}\text { 人間ドック } \\
\text { 未指定 }\end{array}$} & 症列数 & 219 & 61 & 20 & 76 & 119 & 65 & 253 & 27 & 96 & 184 & 133 & 117 & 30 & 117 & 163 & 35 & 168 & 77 \\
\hline & $\%$ & & & & & & & 90.6 & 9.4 & 31.9 & 68.1 & 47.6 & 41.7 & 10.7 & 41.8 & 58.2 & 12.5 & 60.0 & 27.5 \\
\hline & 㱏列数 & 361 & 99 & 36 & 111 & 193 & 120 & 416 & 43 & 158 & 301 & 243 & 172 & 44 & 187 & 272 & 63 & 275 & 121 \\
\hline & $\%$ & & & & & & & 90.6 & 9.4 & 34.4 & 65.6 & 52.9 & 37.5 & 9.6 & 40.7 & 59.3 & 13.7 & 60.0 & 26.3 \\
\hline
\end{tabular}




\section{臨床予防医学委員会委員名簿}

(順不同)

\begin{tabular}{|c|c|c|c|c|}
\hline 名 & 氏 & 院 & 所在地 & 話 \\
\hline 委員長 & 二本杉 & 大阪赤 + 字病院 & 大阪府 & $06-771-5131$ \\
\hline 副委員長 & 鈴 木 豊 明 & 東. 京 警 察 病 院 & 東京都 & $03-263-1371$ \\
\hline$"$ & 藤 間 弘 行 & 藤間 病 & 埼玉県 & $0485-22-0600$ \\
\hline 委 & 笹 森 典 雄 & 牧田 総 合 病 院 & 東京都 & $03-.762-4671$ \\
\hline$"$ & 田中 剛 二 & 南 台 & " & $0423-41-7111$ \\
\hline " & 安藤 幸 夫 & 聖路加 国際病院 & " & $1-5151$ \\
\hline " & 清 瀬 & 三 井 記 念 病 院 & $"$ & $03-862-9111$ \\
\hline$" \prime$ & 大 川 日出夫 & 日 本 鋼 管 病 院 & 神奈川県 & $044-333-5591$ \\
\hline " & 金 澤 鉄 男 & 青森県立 中央病院 & 青森県 & $0177-26-8302$ \\
\hline " & 丹 野 三 男 & 仙 台 市 立 病 院 & 宮城県 & $022-266-7111$ \\
\hline " & 小 関 忠 尚 & 京都第二赤十字病院 & 京都府 & $075-231-5171$ \\
\hline " & 寺 田 由紀夫 & 大阪赤十字病 院 & 大阪府 & $06-771-5131$ \\
\hline " & 宇 津 典 彦 & 国立久留米病院 & 福岡県 & $0942-21-4571$ \\
\hline " & 松 岡 & 病 & 大阪府 & $07212-4-3100$ \\
\hline " & 三木 & 丸 & 兵庫県 & $078-642-1031$ \\
\hline
\end{tabular}

